Hideo Orimo - Eiitsu Nakajima - Motoko Yamamoto

Miyoko Ikejima • Mitsuru Emi • Takashi Shimada

\title{
Association between single nucleotide polymorphisms in the hMSH3 gene and sporadic colon cancer with microsatellite instability
}

Received: February 16, 2000 / Accepted: February 25, 2000

\begin{abstract}
The association between three single nucleotide polymorphisms (SNPs) in the $h M S H 3$ gene and sporadic colon cancer with microsatellite instability (MSI) was analyzed. Of the three SNPs observed in this population, SNPs at residues 235 and 693 were novel, while that at residue 3133 was previously described. The SNPs at residues 235 and 3133 caused amino acid substitutions, V79I and T1045A, respectively. We analyzed the allele frequencies of the three SNPs in samples from 19 patients with sporadic colon cancer with MSI and 90 healthy controls. We found that the V79 allele frequency was significantly higher in the tumor samples than in controls. In addition, the frequency of the G693 allele showed a higher trend in the tumor samples than in controls. These results indicated that some SNPs in the $h M S H 3$ gene were associated with colon cancer with MSI.
\end{abstract}

Key words Association - Allele frequency $\cdot \mathrm{hMSH} 3 \cdot$ Single nucleotide polymorphism (SNP) - Sporadic colon cancer · Microsatellite instability (MSI)

\section{Introduction}

Human MSH3 (hMSH3) is one of the DNA mismatch repair proteins that binds $\mathrm{hMSH} 2$ to form a heterodimer hMutS $\beta$, which recognizes mainly 2-4 loop mismatches (Acharya et al. 1996; Palombo et al. 1996; Drummond et al. 1997; Marra et al. 1998; Genschel et al. 1998; Nakajima et al. 1999). The gene for $h M S H 3$ was cloned (Fujii and Shimada 1989; Watanabe et al. 1996), and located on chromosome

H. Orimo $(\bowtie) \cdot$ E. Nakajima $\cdot$ M. Yamamoto $\cdot$ M. Ikejima

T. Shimada

Department of Biochemistry and Molecular Biology, Nippon

Medical School, 1-1-5 Sendagi, Bunkyo-ku, Tokyo 113-8602, Japan

Tel. +81-3-3822-2131 (Ext.5240); Fax +81-3-5814-8156

e-mail: Orimo_Hideo/bmb@nms.ac.jp

M. Emi

Department of Molecular Biology, Institute of Gerontology, Nippon

Medical School, Kawasaki, Japan 5q11-13 (Anagnou et al. 1988). Defective mismatch repair causes microsatellite instability (MSI) that indicates hypermutability (Modrich and Lahue 1996). Frameshift mutations in the hMSH3 gene are considered to affect the tumorigenesis of colon cancer with MSI (Malkhosyan et al. 1996; Risinger et al. 1996; Ikeda et al. 1998; Orimo et al. 1999). In addition, the repeat number of a 9-bp repeat polymorphism in exon 1 of the $h M S H 3$ gene (Nakajima et al. 1995) was altered in a sporadic colon cancer with MSI (Orimo et al. 1999).

The genes for the other mismatch repair proteins, hMSH2 and hMLH1, were often mutated in sporadic colon cancer with MSI (Eshleman and Markowitz 1996). However, the role of the mismatch repair protein genes in a genetic background of sporadic colon cancer with MSI has not been well investigated. Particularly, there have been no reports on association between the $h M S H 3$ gene and sporadic colon cancer with MSI. We report here an association study between three single nucleotide polymorphisms (SNPs) in the $h M S H 3$ gene and sporadic colon cancer with MSI.

\section{Subjects and methods}

Samples. Genomic DNA of 19 Japanese patients with sporadic colon cancer with MSI was extracted from both normal and cancerous tissues, as described previously (Orimo et al. 1998). As a control, genomic DNA of 90 healthy Japanese volunteers was extracted from peripheral blood, or hair. The samples were extracted after informed consent had been obtained.

Microsatellite instability (MSI). The following markers were employed to estimate MSI, as described elsewhere (Orimo et al. 1998). BAT25, BAT26, and the $(\mathrm{A})_{10}$ repeat of transforming growth factor (TGF)- $\beta$ RII were used for the mononucleotide repeat, and DCC, D5S107, D17S261, and the $(\mathrm{GT})_{3}$ repeat of TGF- $\beta$ RII were used for the dinucleotide repeat. 
Polymerase chain reaction-single-strand conformation polymorphism (PCR-SSCP). A PCR-SSCP analysis was performed, using $\left[\gamma^{-3} \mathrm{P}\right] \mathrm{ATP}$-labeled primers that amplified 24 exons based on the genomic sequence of the $h M S H 3$ gene (Watanabe et al. 1996). The nucleotide sequences of the PCR primers are available upon request. The PCR conditions were described elsewhere (Orimo et al. 1999). The PCR products were heat-denatured, applied to a $0.5 \times$ MDE gel (FMC BioProducts, Rockland, ME, USA), and electrophoresed at $6 \mathrm{~W}$ for $12 \mathrm{~h}$ at room temperature. The gel was dried and exposed to an X-ray film at $-70^{\circ} \mathrm{C}$ for $3-5$ days.

Direct nucleotide sequencing. Each SSCP band was cut out and eluted with water, and then the eluate was re-amplified with nonlabeled primers. The PCR product was labeled using an ABI PRISM Dye Terminator Cycle Sequencing Kit, and nucleotide sequencing was carried out with an ABI 373 autosequencer (Perkin-Elmer, Norwalk, CT, USA).

Digestion with restriction enzymes. To detect a single base substitution, PCR was carried out with nonlabeled primers and the PCR product was digested with one of the following restriction enzymes; $B s a \mathrm{AI}$ for the polymorphism at cDNA residue 235 in exon 1, AciI for residue 693 in exon 4, and HhaI for residue 3133 in exon 23. The digested PCR products were analyzed on $8 \%$ polyacrylamide gel electrophoresis. The numbers of cDNA residues were calculated from the first ATG (Fujii and Shimada 1989).

Statistical analysis. The $\chi^{2}$ test was used to analyze significant differences in allele frequencies of the polymorphisms between the samples from the normal subjects and the tumor samples. A level of $P<0.05$ was considered statistically significant.

\section{Results and discussion}

By PCR-SSCP-direct nucleotide sequencing, we found single nucleotide polymorphisms in exons 1,4 , and 23 of the hMSH3 gene in colon cancer samples. They were not somatic changes, because cancer samples and noncancerous tissues from the same patients showed identical genotypes. In the reported sequence (Watanabe et al. 1996), residue 235 in exon 1 is $\mathrm{G}$, and the amino acid residue at codon 79 is valine. We found a base substitution in two samples in which residue 235 was $\mathrm{A}$, and the amino acid residue at codon 79 would change to isoleucine. In exon 4, residue 693 is $\mathrm{G}$ and the amino acid residue at codon 231 is proline, but nine samples showed A at 693, which would not change the amino acid residue at codon 231 . The base substitutions in exons 1 and 4 were novel. In exon 23, residue 3133 is $\mathrm{A}$ and the amino acid residue at codon 1045 is threonine, but nine samples showed $\mathrm{G}$ at 3133 and the amino acid residue at codon 1045 would change to alanine. This base substitution was reported in a $h M S H 3$ cDNA (Acharya et al. 1996), but its allele frequency has not been investigated.
We searched for these three base substitutions in the DNA samples from the 90 healthy Japanese volunteers by digestion with restriction enzymes. The characteristics of the base substitutions are summarized in Table 1. Because the base substitution in exon 4 did not change the amino acid residue, it was a polymorphism. The other two base substitutions changed the encoded amino acid residues, but these base substitutions were common in the normal population, suggesting that they were also polymorphisms.

An association study was performed between the three SNPs and sporadic colon cancer with MSI. We analyzed 19 MSI tumor samples and the 90 healthy control samples. Table 2 shows the allele frequencies of each SNP in the tumor samples and the samples of the healthy controls. Although the number of tumor samples was not very large, it was possible to calculate significant differences between tumor samples and controls. The Val79 (G235) allele frequency was significantly higher in the tumor samples than in controls $(P<0.05)$. The $\mathrm{G} 693$ at codon 231 allele frequency was higher in the tumor samples than in controls, although the trend did not show a significant difference $(P=0.052)$. No difference was found in 1045 (Thr or Ala) allele frequency between the tumor samples and controls.

Because Val79 is the more common allele, hMSH3 function with Val79 may not be defective. In addition, Val79 was not in linkage disequilibrium with the other two SNPs. The frequency of seven haplotypes of the three SNPs showed no significant differences between 28 informative chromosomes in tumor samples and 82 informative chromosomes in controls (data not shown). However, the Val79 allele could be in linkage disequilibrium with other SNPs, which would change the protein function, or with mutations in adjacent genes, which may be associated with the tumorigenesis.

Defective function of the hMSH3 gene may influence the tumorigenesis of colon cancer with MSI (Malkhosyan et al. 1996; Risinger et al. 1996; Ikeda et al. 1998; Orimo et al. 1999). Although we did not search for cancers without MSI, which are not considered to be associated with defective mismatch repair, the present study revealed that some SNPs

Table 1. Characteristics of the polymorphisms in the $h M S H 3$ gene

\begin{tabular}{ccll}
\hline cDNA residue & Codon & $\begin{array}{l}\text { Digestion with } \\
\text { restriction enzymes }\end{array}$ & Heterozygosity \\
\hline 235 & 79 & BsaAI & \\
G & Val & $149+22 \mathrm{bp}$ & 0.32 \\
A & Ile & 171 & \\
693 & 231 & Aci & \\
G & Pro & $171+151 \mathrm{bp}$ & 0.49 \\
A & Pro & 322 & \\
3133 & 1045 & Hha & \\
A & Thr & $255 \mathrm{bp}$ & 0.34 \\
G & Ala & $221+34$ & \\
\hline
\end{tabular}

At residue 235, the size of the polymerase chain reaction (PCR) fragment (171 bp) corresponded to three repeats in the 9-bp repeat polymorphism (Nakajima et al. 1995). Six repeat samples showed a 198-bp fragment, and the digested allele yielded fragments of $176+22 \mathrm{bp}$. Heterozygosity was calculated in 90 healthy controls according to the method of Chakraborty et al. (1988) 
Table 2. Genotypes and allele frequencies of the polymorphisms in the hMSH3 gene in MSI tumor samples and healthy controls

\begin{tabular}{|c|c|c|c|c|c|c|}
\hline \multirow{2}{*}{$\begin{array}{l}\text { cDNA residue } \\
235 \\
(\text { codon } 79)\end{array}$} & \multirow[t]{2}{*}{$n$} & \multicolumn{3}{|l|}{ Genotypes } & \multicolumn{2}{|c|}{ Allele frequency } \\
\hline & & $\begin{array}{l}\mathrm{G} / \mathrm{G} \\
(\mathrm{Val} / \mathrm{Val})\end{array}$ & $\begin{array}{l}\text { G/A } \\
\text { (Val/Ile) }\end{array}$ & $\begin{array}{l}\mathrm{A} / \mathrm{A} \\
\text { (Ile/Ile) }\end{array}$ & $\begin{array}{l}\mathrm{G} \\
(\mathrm{Val})\end{array}$ & $\begin{array}{l}\text { A } \\
\text { (Ile) }\end{array}$ \\
\hline Controls & $81(162)$ & 55 & 19 & 7 & $129(0.80)$ & $33(0.20)$ \\
\hline Tumors & $9(38)$ & 17 & 2 & 0 & $\begin{array}{r}36(0.95) \\
\chi^{2}=4.87\end{array}$ & $\begin{array}{l}2(0.05) \\
0.027^{*}\end{array}$ \\
\hline $693(\operatorname{codon} 231)$ & & $\mathrm{G} / \mathrm{G}$ & $\mathrm{G} / \mathrm{A}$ & $\mathrm{A} / \mathrm{A}$ & $\stackrel{n}{\mathrm{G}}$ & A \\
\hline Controls & $90(180)$ & 26 & 50 & 14 & $102(0.57)$ & $78(0.43)$ \\
\hline Tumors & $19(38)$ & 10 & 8 & 1 & $\begin{array}{r}28(0.74) \\
\chi^{2}=3.78\end{array}$ & $\begin{array}{l}10(0.26) \\
0.052\end{array}$ \\
\hline $\begin{array}{l}3133 \\
(\text { codon 1045) }\end{array}$ & & $\begin{array}{l}\text { A/A } \\
\text { (Thr/Thr) }\end{array}$ & $\begin{array}{l}\text { A/G } \\
\text { (Thr/Ala) }\end{array}$ & $\begin{array}{l}\text { G/G } \\
\text { (Ala/Ala) }\end{array}$ & $\begin{array}{l}\text { A } \\
\text { (Thr) }\end{array}$ & $\begin{array}{l}\mathrm{G} \\
\text { (Ala) }\end{array}$ \\
\hline Controls & 89 (178) & 55 & 28 & 6 & $138(0.78)$ & $40(0.22)$ \\
\hline Tumors & $19(38)$ & 10 & 8 & 1 & $\begin{array}{r}28(0.74) \\
\chi^{2}=0.26\end{array}$ & $\begin{array}{l}10(0.26) \\
0.61\end{array}$ \\
\hline
\end{tabular}

* Significant difference $(P<0.05)$

Nine control samples at residue 235 and one control sample at residue 3133 were not determined. Numerals in parentheses in the $n$ column indicate the number of chromosomes. In the allele frequency column, numerals show the number of chromosomes, and numerals in parentheses show allele frequency

MSI, Microsatellite instability

in the $h M S H 3$ gene were associated with sporadic colon cancer with MSI in a Japanese population.

Acknowledgements We thank Dr. Atsushi Watanabe for valuable discussion and Dr. Kazuhiro Kijima for technical assistance. This study was supported in part by Grants-in-Aid for Scientific Research on Priority Areas (07272103 and 08280104) from the Ministry of Education, Science, Sports, and Culture of Japan.

\section{References}

Acharya S, Wilson T, Gradia S, Kane MF, Guerrette S, Marsischky GT, Kolodner R, Fishel R (1996) hMSH2 forms specific mispairbinding complexes with hMSH3 and hMSH6. Proc Natl Acad Sci USA 93:13629-13634

Anagnou NP, Antonarakis SE, O'Brien SJ, Modi WS, Nienhuis AW (1988) Chromosomal localization and racial distribution of the polymorphic human dihydrofolate reductase pseudogene (DHFRP1). Am J Hum Genet 42:345-352

Chakraborty R, Smouse PE, Neel JV (1988) Population amalgamation and genetic variation: observations on artificially agglomerated tribal polulations of Central and South America. Am J Hum Genet 43:709-725

Drummond JT, Genschel J, Wolf E, Modrich P (1997) DHFR/MSH3 amplification in methotrexate-resistant cells alters the hMutSa/ hMutS $\beta$ ratio and reduces the efficiency of base-base mismatch repair. Proc Natl Acad Sci USA 94:10144-10149

Eshleman JR, Markowitz SD (1996) Mismatch repair defects in human carcinogenesis. Hum Mol Genet 5:1489-1494

Fujii H, Shimada T (1989) Isolation and characterization of cDNA clones derived from the divergently transcribed gene in the region upstream from the human dihydrofolate reductase gene. J Biol Chem 264:10057-10064
Genschel J, Littman SJ, Drummond JT, Modrich P (1998) Isolation of MutS $\beta$ from human cells and comparison of the mismatch repair specificities of MutS $\beta$ and MutS $\alpha$. J Biol Chem 273:19895-19901

Ikeda M, Orimo H, Moriyama H, Nakajima E, Matsubara N, Mibu R, Tanaka N, Shimada T, Kimura A, Shimizu K (1998) Close correlation between mutations of E2F4 and $h M S H 3$ genes in colorectal cancers with microsatellite instability. Cancer Res 58:594-598

Malkhosyan S, Rampino N, Yamamoto H, Perucho M (1996) Frameshift mutator mutations. Nature 382:499-500

Marra G, Iaccarino I, Lettieri T, Roscilli G, Delmastro P, Jiricny J (1998) Mismatch repair deficiency associated with overexpression of the MSH3 gene. Proc Natl Acad Sci USA 95:8568-8573

Modrich P, Lahue R (1996) Mismatch repair in replication fidelity, genetic recombination, and cancer biology. Annu Rev Biochem 65:101-133

Nakajima E, Orimo H, Ikejima M, Shimada T (1995) Nine-bp repeat polymorphism in exon 1 of the $h M S H 3$ gene. Jpn J Human Genet 40:343-345

Nakajima E, Ikejima M, Watanabe A, Shimada T (1999) Identification of the protein components of mismatch binding complexes in human cells using a gel-shift assay. FEBS Lett 453:85-89

Orimo H, Ikejima M, Nakajima E, Emi M, Shimada T (1998) A novel missense mutation and frameshift mutations in the type II receptor of transforming growth factor- $\beta$ gene in sporadic colon cancer with microsatellite instability. Mutat Res 382:115-120

Orimo H, Nakajima E, Ikejima M, Emi M, Shimada T (1999) Frameshift mutations and a length polymorphism in the $h M S H 3$ gene and the spectrum of microsatellite instability in sporadic colon cancer. Jpn J Cancer Res 90:1310-1315

Palombo F, Iaccarino I, Nakajima E, Ikejima M, Shimada T, Jiricny J (1996) hMutS $\beta$, a heterodimer of hMSH2 and hMSH3, binds to insertion/deletion loops in DNA. Curr Biol 16:1181-1184

Risinger JI, Umar A, Boyd J, Berchuck A, Kunkel TA, Barrett JC (1996) Mutation of MSH3 in endometrial cancer and evidence for its functional role in heteroduplex repair. Nature Genet 14:102-105

Watanabe A, Ikejima M, Suzuki N, Shimada T (1996) Genomic organization and expression of the human $M S H 3$ gene. Genomics 31:311-318 